\title{
EXTRACTION OF BIOLIQUID AND QUANTITATIVE DETERMINATION OF SATURATES, AROMATICS AND ORGANIC POLARS FROM FERMENTED BANANA (MUSA SAPINTUM) LEAVES
}

\author{
${ }^{1}$ Ekwenchi, M.M. and ${ }^{2}$ Yaro, M.N. \\ ${ }^{1}$ Department of Pure and Industrial Chemistry, University of Jos, Plateau State \\ ${ }^{2}$ Department of Chemistry, Federal University, Dutse, Jigawa State
}

\begin{abstract}
Bioliquid generated from the leaves of banana (Musa sapintum) through anaerobic fungal degradation was obtained by soxhlet extraction using absolute methanol as solvent at $60^{\circ} \mathrm{C}$ for 72 hours. The bioliquid extracted was recovered from the extracting solvent by evaporation using rotary evaporator. The extract obtained was concentrated to a constant weight using hot plate at $37^{\circ} \mathrm{C}$. The concentrated bioliquid was dissolved in a solution mixture of methanol and hexane and the maltenes content of the bioliquid was separated from the asphaltenes by precipitation. The maltenes obtained was further separated into fractions (saturates, monoaromatics, diaromatics, polyaromatics and organic polars) by column chromatography. The analysis revealed that the amounts of saturates, monoaromatics, diaromatics, polyaromatics and organic polars in $72.50 \mathrm{mg}$ maltenes analysed were $38.00 \mathrm{mg}, 9.20 \mathrm{mg}, 6.70 \mathrm{mg}, 11.30 \mathrm{mg}$ and $3.80 \mathrm{mg}$ respectively. Keywords: Bioliquid; maltenes; asphaltenes; saturates; aromatics; oganic polars.
\end{abstract}

\section{INTRODUCTION}

Bioliqud is an extract obtained from the fermented slurry generated through anaerobic fungal degradation of organic substrate. Bioloquid is relatively heavier than biogas and it is usually composed of maltenes and asphaltenes as reported by Yaro (2011). In bioliquid, the maltenes always exceed the asphaltenes, though there is considerable variation in the ratio as reported by Ekwenchi et al (1984). The fact that bioliquid is very closely related to petroleum in terms of source and composition, Yaro (2011) classified bioliquid on the basis of petroleum classification by Brame and King (1967) as follows:

i. Paraffinic bioliquid, if the side chains are over $75 \%$

ii. Naphthenic bioliquid, if the naphthenic rings are over $70 \%$.

iii. Asphaltic bioquid, if the asphaltenes contents exceed $60 \%$

iv. Paraffinic - naphthenic bioliquid, if the side chains are $60-70 \%$ and naphthenic rings are over $20 \%$.

v. Naphthenic - aromatic, if the naphthenic rings and aromatic rings exceed $30 \%$

Maltenes are the fraction of residuum, which is insoluble in liquid propane but soluble in n-pentane (Oladapo, 1988). Maltenes are generated from organic substrate as a result of microbial activities under favourable degradation conditions. Maltenes are generally composed of saturates (n-alkanes, isoalkanes and cyclo-alkanes), aromatics and small quantities of resins and organic polars as reported by Yaro (2011). Maltenes are relatively more paraffinic than asphaltenes and contain less $\mathrm{N}, \mathrm{S}$, and $\mathrm{O}$ as pointed out by Oladapo (1988). The simple way to compare the paraffinicity of any fossil fuel or its fraction is by showing ratio of $\mathrm{C}$ to $\mathrm{H}(\mathrm{C} / \mathrm{H})$. The higher the $C / H$, the more the maltenes content as reported by Ekwenchi et al .(1984).

Asphaltenes are described as the solid, amorphous, black to dark brown particles dissolved or dispersed constituents of crude oil or other bitumens that are soluble in carbon disulphide $\left(\mathrm{CS}_{2}\right)$ but insoluble in paraffin naphthas. Asphaltenes consist mainly of $\mathrm{C}, \mathrm{H}$ and some quantities of $\mathrm{N}, \mathrm{S}$ and $\mathrm{O}$; they are generally aromatics in nature; and their molecules consist of 10-20 condensed aromatic and naphthenic rings with paraffinic and naphthenic side chains as reported by Oladapo (1988).

Saturates are a fraction of maltenes which are composed of n-alkanes, iso-alkanes and cyclo-alkanes as reported by Yaro (2011).

Aromatics are a special class of cyclic compounds based on benzene $\left(\mathrm{C}_{6} \mathrm{H}_{6}\right)$, a 6-carbon ring compound from which all other aromatic compounds are derived, e.g phenylamine (aniline), phenol, etc. and some derivatives may also contain straight carbon chains as side chains as pointed out by Ababio (1985). Aromatic hydrocarbons in general were so named because many of them have strong aromas (smells) as pointed out by Bajah and Godman (1975). Aromatic compounds can be monoaromatics, diaromatics or polyaromatics depending upon the number of rings per molecule and, in any of these circumstances, the $\pi$-electron must be equal to $(4 n+2)$, where $n$ is the number of ring as pointed out by Aliyu (1992).

Organic polars can simply be described as hydrocarbon Compounds which have dipole moment due to the presence of $\mathrm{S}, \mathrm{O}, \mathrm{N}$ or halogens in their molecules. Examples of organic polar compounds include: ethers, ketones, substituted alkanes, substituted aromatic compounds, cyclo-alkanes etc. as pointed by Dagari (2006). 
The research is aimed at fermenting of banana leaves, extracting of bioliquid from fermented slurry, isolating of maltenes and asphaltenes components of the bioliquid; and determining the amounts of satrurates, monoaromatics, diaromatics, polyaromatic and organic polars in the maltenes.

\section{MATERIALS AND METHODS}

The material used was fermented slurry of Musa sapintum leaves obtained through anaerobic fungal degradation. The chemicals/reagents used were alumina, benzene, diethyl ether, hexane, methanol and silica gel. The apparatus used were weighing balance, soxhlet extracting set, oven, heating mantle, hot plate, thermometre, rotary evaporator, refrigerator, fume cupboard, glass column and other glass wares.

\section{Fermentation of Banana Leaves}

$4.0 \mathrm{~g}$ of ground and sieved banana leaves of particles size $<250 \mu \mathrm{m}$ was dissolved in $25.0 \mathrm{~cm}^{3}$ distilled water containing $0.18 \mathrm{~g}$ yeast and placed in a reactor. The reactor was made airtight and placed in water bath maintained at $33^{\circ} \mathrm{C}$ for 7 days, after which the reactor was opened and the content (fermented slurry) was collected for bioliquid extraction.

\section{Extraction of Bioliquid from Fermented Slurry}

The fermented slurry was first drained by decantation process to remove excess water, after which it was subjected to bioliquid extraction. The extraction was carried out by soxhlet extraction using absolute methanol at $60^{\circ} \mathrm{C}$ for 72 hours. The bioliquid extracted was recovered from the extracting solvent by evaporation using rotary evaporator, after which it was concentrated to a constant weight using hot plate at $37^{\circ} \mathrm{C}$ in a fume cupboard.

\section{Precipitation of Asphatenes (Isolation of Maltenes)}

One gramme $(1.0 \mathrm{~g})$ of the concentrated bioliquid extracted was dissolved in a mixture of $1 \mathrm{~cm}^{3}$ methanol and $40 \mathrm{~cm}^{3}$ hexane and kept in refrigerator for $24 \mathrm{hrs}$. The maltenes (deasphaltened oils) being the soluble component of the bioliquid remained in the solution while the asphaltenes being the insoluble component settled down. The solution was carefully decanted, and both the maltenes (solution) and the asphaltenes (precipitate) were separately dried in fume cupboard.

\section{Separation of Saturates, Aromatics and Polar} Compounds by Column Chromatography

For the separation of components of the maltenes obtained into saturates, monoaromatics, diaromatics, polyaromatics and organic polars, a glass column of $40 \mathrm{~cm}$ length and $0.85 \mathrm{~cm}$ internal diameter with bed volume of $22.72 \mathrm{~cm}^{3}$ was packed with silica gel of particle size $0.063-0.074 \mathrm{~nm}$ (activated at $100^{\circ} \mathrm{C}$ over night in an oven) and alumina of particles size $3.74 \mu \mathrm{m}$ in the ratio $1: 2$ (silica gel to alumina). The sample (maltenes) to packing material (sorbent) ratio was $1: 70$ for silica gel and $1: 140$ for alumina as adopted by Mailabari (1983), with a column maximum load capacity of $72.5 \mathrm{mg}$. (See Appendices 1,2 and 3 for more details).

The column was carefully packed with silica gel followed by alumina, which is relatively denser than the silica gel to allow for uniform sample size densities and avoid void volumes. The packed column was first washed with $30 \mathrm{~cm}^{3}$ hexane before the separation starts. The sample was then applied as a concentrated solution of hexane and, eluted in five (5) separate fractions with the following solvents of $30 \mathrm{~cm}^{3}$ each: for the separation of saturates, hexane was used as eluent; for the separation of monoaromatics, $5 \%$ benzene in hexane was used as eluent; for the separation of polyaromatics, a solution made of $20 \mathrm{~cm}^{3}$ benzene, $20 \mathrm{~cm}^{3}$ diethyl ether and $60 \mathrm{~cm}^{3}$ methanol was used as eluent; and for the separation organic polars, methanol was used as eluent. The fractions collected were separately dried in a fume cupboard and weighed.

\section{RESULTS}

All the results obtained in this work are shown in Tables 1 and 2 below: Table 1 shows the components and quantity of the bioliquid generated from $4.0 \mathrm{~g}$ banana leaves. The table also shows the amounts of maltenes and asphaltenes extracted from $3.970 \mathrm{~g}$ bioliquid. Table 2 gives the fractions (in $\mathrm{mg}$ ) of maltenes component of the bioliquid extracted.

Table 1: Quantity and Components of Bioliquid Extracted from Fermented Slurry

\begin{tabular}{ll}
\hline Component & Quantity (g) \\
\hline Bioliquid extracted & 3.970 \\
Maltenes content of the bioliquid & 2.114 \\
Asphaltenes content of the bioliquid & 1.856 \\
\hline
\end{tabular}

Table 2: Fractions of $72.5 \mathrm{mg}$ Maltenes Components Separated by Column Chromatography.

\begin{tabular}{ll}
\hline Fraction & Quantity $\mathbf{( m g )}$ \\
\hline Saturates & 38.00 \\
Monoaromatics & 9.20 \\
Diaromatics & 6.70 \\
Polyaromatics & 11.30 \\
Organic Polars & 3.80 \\
\hline
\end{tabular}




\section{DISCUSSION}

Table 1 shows the amount of bioliquid generated from the fermented Musa sapintum leaves used and its components. The yield of bioliquid observed is attributed to the conversion of the organic component of the substrate (Musa sapintum leaves) by the microbes responsible for the degradation of the substrate into bioliquid during the fermentation process. Since production of bioliquid occurs simultaneously with the production of biogas, this could therefore be explained by the statement of Khandelwal and Mahdi (1986), which says biogas production from organic substrates is a microbial process in which different groups of bacterial act upon a complex organic matters in the absence of air.

The relative high maltenes and low asphaltenes contents also shown in Table 1 maybe associated with the conversion of some of the asphaltenes into maltenes by the microbes. Because some microbes have the ability to synthesize alkanes from asphaltenes by dearomatization of the aromatics as reported by Ekwenchi et al (1990). It could also be associated with the consumption of the asphaltenes by the microbes. This is because during fermentation, microbes use polymeric compounds in the substrate as source of carbon for energy and nitrogen for growth as pointed out by Garba (1998).

Table 2 shows the result obtained for the analysis of maltenes by column chromatography, from the result, it could be seen that the fractions were in the order: saturates $>$ polyaromatics $>$ monoaromatics $>$ diaromantics $>$ organic polars. The relative high saturates, and low polar and aromatic compounds maybe associated with the conversion of most of the diaromatics and polar compounds into saturates. This is because some micro-organisms have the ability to synthesize alkanes from diaromatics by

\section{REFERENCES}

Ababio, O.Y. (1985): New School Chemistry Certificate Science Series, (Revised Edition), African FEB Publishers, Ibadan Nigeria Ltd. Pp 461466.

Aliyu, M. (1992): Aromatic Compounds from /Natural Products. A paper presented during Chemical Society Week at Usmanu Danfodiyo University, Sokoto - Nigeria.

Bajah, S.T. and Godman, A. (1975): Chemistry: A New CertificateApproach, (New edition) Longman Publishers, Ibadan.. Pp. 228.

Bird, C.W Lynch, J.M and Pirt, S.J. (1974): Chemistry and Industry. A Publication of the Division of Petroleum Chemistry of American Chemical Society, New York Pp1

Brame, J.S. and King, J.G. (1967): Fuel; solid, liquid and gaseous ( $6^{\text {th }}$ Edition), Edward Amord Publishers Ltd., London

Dagari, M.S. (2006): Basic Physical Chemistry, with over 200 Solved Problems. (Second Edition): Gidan Dabino Publishers, Kano . Pp 46.

Ekwenchi, M.M., Lown, E.M., Montgomery D.S. and Strautz, O.P, (1984): High Temperature Pyrolysis of Petroleum Asphaltenes; AOSTRA Journal of Research, 1 (2) dearomatization and from polars by using the oxygen, sulphur, nitrogen or halogen atom in the polar compound for metabolism as pointed out by Ekwenchi et al (1990). The high saturates and low polars may also be associated with the conversion of ployaromatic compounds by the microorganism during fermentation. This is based on the assumption that the microorganisms might have grown by using the polyaromatic hydrocarbons in the substrate as a carbon source for energy supply during fermentation (Bird et al, 1974).

\section{CONCLUSION}

The research revealed that important organic compounds such as saturates, aromatics and polar compounds can be generated and isolated from banana leaves by anaerobic fungal degradation; the amount of maltenes generated from the bioliquid was relatively higher than the amount of asphaltenes and; the fraction of maltenes were in the order: saturates $>$ polyaromatics $>$ monoaromatics > diaromatics $>$ organic polars.

\section{RECOMMENDATIONS}

i. Research should be conducted in order to separate and characterize the n-alkanes, isoalkanes and cyclo-alkanes from the saturates generated from plant source.

ii. Research should also be conducted on the possibility of using saturates generated from plant source through anaerobic fungal degradation as biofuels and lubricants.

iii. Studies should be made on the factors that can increase the yield of bioliquid from plant and other biodegradable wastes in order to minimize pollution in the environment.

Ekwenchi, M.M., Akunwanne, B.U., Okeke N.R. and Ekpeyong K.I. (1990): Gaseous Fuel Production by Fungal Degradation of Elephant grass, Fuel, 69. Pp 1569 - 1572.

Garba, B. (1998): Studies on the Chemical Composition of Biogas and Kinetics of its Production at Varying Temperature, Unpublished Ph. D Thesis in the Department of Pure and Applied Chemistry, Usmanu Danfodiyo University, Sokoto - Nigeria, Pp1103

Khandelwal, K.C. and Mahdi, S.S (1986): Biogas Technology: A practical handbook, Mcgraw Hill Publishing Company Ltd, New Delhi-India Pp 2-51.

Mailabari B.K. (1983): Chemical Composition of Total Hydrocarbons and Quantitative Determination of $\mathrm{n}$-alkanes in Nigerian Bitumen, Unpublished B.Sc. Project, Dept. of Chemistry University of Jos.

Pp 2-10.

Oladapo, A.O. (1988): Estimation of Maturation of Petroleum Asphaltenses and Maltenes. Unpublished B.Sc Project. University of Jos. Pp. 1- 
Yaro, M.N. (2011): Studies on Biogas and Bioliquid Production by Fungal Degradation of Banana (Musa sapintum) leaves. Unpublished Ph.D
Thesis in the Dept of Pure and Industrial Chemistry, University of Jos-Nigeria Pp. 107221

\section{Appendix 1}

Packing of Chromatographic Column with Silica Gel and Alumina Bed volume of the column (BV) Length of the column $(\mathrm{L})=40 \mathrm{~cm}$

Internal diameter of the column $(D)=0.85 \mathrm{~cm}$

Radius of the column $(r)-D / 2=\underline{0.85 \mathrm{~cm}}-0.425 \mathrm{~cm}$ 2

Cross sectional area of the column $(\mathrm{A})=\pi r^{2}$

But $\pi=3.142$

$\therefore A=3.142(0.425 \mathrm{~cm})^{2}$

$$
=0.568 \mathrm{~cm}^{2}
$$

The bed volume (BV) of the column is given by $A \times L$,

$$
\begin{aligned}
\therefore \mathrm{BV} & =0.568 \mathrm{~cm}^{2} \times 40 \mathrm{~cm} \\
& =22.72 \mathrm{~cm}^{3}
\end{aligned}
$$

\section{Appendix 2}

Packing Ratio of Silica gel to Alumina in the Column

For one part of the column, the volume to be occupied by Silica gel

$$
\begin{gathered}
=\frac{\mathrm{BV}}{3} \\
\frac{22.72 \mathrm{~cm}-}{3} \\
=7.57 \mathrm{~cm}^{3}
\end{gathered}
$$

(For one part of the column, the bed volume was divided by 3 because

$$
\text { volume }=\mathrm{L} \times \mathrm{L} \times \mathrm{L} \text { ) }
$$

So, the volume occupied by the silica gel $=7.57 \mathrm{~cm}^{3}$

But quantity raio of silica gel to alumina $=1: 2$

$\therefore$ the volume occupied by alumina $=7.57 \mathrm{~cm}^{\prime} \times 2=15.15 \mathrm{~cm}^{3}$

For $1 \mathrm{~cm}^{3}$ of silica gel, the weight of silica gel $=0.6771 \mathrm{~g}$ (i.e. density of silica gel $=0.6771 \mathrm{~g} / \mathrm{cm}^{3}$ )

Thus, the mass (weight) of silica gel packed in the column

$=$ density of silica gel $x$ volume of silica gel

$$
=0.6771 \mathrm{~g} / \mathrm{cm}^{3} \times 7.57 \mathrm{~cm}^{3}=5.13 \mathrm{~g}
$$

For $1 \mathrm{~cm}^{3}$ of alumina, the weight of alumina $=0.6684 \mathrm{~g}$

$$
=\text { (i.e. density of alumina }=0.6684 \mathrm{~g} / \mathrm{cm}^{3} \text { ) }
$$

$\therefore$ The mass (weight) of alumina packed in the column

$$
=\text { density of alumina } x \text { volume of alumina }
$$

$$
=0.6684 \mathrm{~g} / \mathrm{cm}^{3} \times 15.15 \mathrm{~cm}^{3}
$$

$$
=10.13 \mathrm{~g}
$$

Appendix 3

\section{Sample to Packing Ratio}

For silica gel, the sample to packing material ratio $=1: 70$

$$
\text { But the rate of the silica gel } \quad=5.13 \mathrm{~g}
$$

$\therefore$ the weight of the sample $\quad=\underline{5.13 \mathrm{~g}}$

$$
\begin{aligned}
& 70 \\
& =0.073 \mathrm{~g} \\
& =73.0 \mathrm{mg}
\end{aligned}
$$

For alumina, the sample to packing material ratio $=1: 140$,

$$
\text { But the weight of alumina }=10.13 \mathrm{~g}
$$

$$
\begin{aligned}
& \therefore \text { the weight of the sample }=\frac{10.13 \mathrm{~g}}{140}=0.072 \mathrm{~g}=72.0 \mathrm{mg} \\
& \qquad \begin{aligned}
& =\frac{73.0 \mathrm{mg}+72.0 \mathrm{mg}}{2} \\
& =72.5 \mathrm{mg}
\end{aligned}
\end{aligned}
$$

